\title{
Evolution of Individual Status in International Law
}

\author{
Sayel Mofleh Momani ${ }^{1}$, Maher Saleh Al-Jubouri ${ }^{1} \&$ Noor Akef Al-Dabbas ${ }^{2}$ \\ ${ }^{1}$ Irbid National University, Irbid, Jordan \\ ${ }^{2}$ Amman Arab University, Amman, Jordan \\ Correspondence: Sayel Mofleh Momani, Irbid National University, Irbid, Jordan.
}

Received: February 1, 2018

Accepted: March 25, 2018

Online Published: November 30, 2018

doi:10.5539/jpl.v11n4p116

URL: https://doi.org/10.5539/jpl.v11n4p116

\begin{abstract}
Each legal system has individuals who are addressed with its rules and that the legal rules of the legal system are designed to regulate the relationship between these individuals, and one individual can have legal personality in more than one legal system.

The legal personality of these individuals is highlighted by the relationship between them and the legal system in which arranges for them rights and impose obligations on them.

The rights and duties of a legal person are not the same; they vary from person to person within the same legal system, and vary from one legal system to another.

With regard to the international legal order, it has its own international legal persons, foremost among them States.

As for the individual, his legal status under general international law is still not clearly defined and is a subject of controversy among the jurists and interpreters of international law. We will present the position of international jurisprudence on the status of the individual in the first demand, the rules of international law that address individuals directly in a second demand, and the right to submit complaints and claims at the international level in a third demand.
\end{abstract}

Keywords: individual status, international law, international jurisprudence

\section{Introduction}

There is nothing controversial more than the position of international law in general, from the individual (the natural person) or the status of the individual in the branches of this law if we take into account that the status of the individual develops and the process in different views and formed different formations and also took into account that the branches of this law has also expanded in scope and comprehensiveness in response to the developments that included the vocabulary of this law so that the pillars of this law and its entitlements are also under the influence of evolution and continuous change.

Since the rules of international law, as a subset of general international law, are the most developed and most dynamic rules in the locus of theory and practice, it was natural for an individual to have a distinct importance and an unconventional status or he breaks the traditional status he enjoyed.

In the second half of the last century, the international legal system witnessed a remarkable development in the interest of individuals, although this interest has emerged in a limited range, with the individual becoming gradually integrated, especially after the end of World War II Under the umbrella of international legal norms, because of the growing international interest in organizing individuals more than ever, although international legal norms do not address the individual directly so far $^{1}$. In other words, the individual is not directly involved in establishing an international legal relationship with States or with international organizations to date.

It can be said that the events of the international community before and during the Second World War gave rise to the idea of international attention to the affairs of the individual in a clear and intensive manner, where the world witnessed at that time unimaginable horrors, which were serious crimes and gross violations Human rights and fundamental freedoms.

\footnotetext{
${ }^{1}$ Burhan Ghalioun et al. (2005) An Analytical Perspective on Human Rights through the Charters and Organizations' Declarations, 13-14 in: Human Rights: Global, Islamic and Arab Perspectives.
} 
It is important to determine the legal status of the individual in international humanitarian law as important as it is to give the individual (man) what he or she should undertake from a legal position that is at least compatible with the designation of this law as a humanitarian law, that is, it is the law of man, the individual, (the natural person). Giving the individual the place he deserves in the rules of this law will determine the protection approach and the pace of its approval to the extent that the violation of this protection or violation of its rules constitutes an international crime.

\subsection{Research Problem}

In the twentieth century, international law has evolved in the field of individual protection within the framework of international human rights law, the term that emerged from 1948 with the Universal Declaration of Human Rights, following the conclusion of several international conventions such as the 1966 International Covenant on Civil and Political Rights, the second concerns economic, social and cultural rights. The position of the individual developed under the international law.

\subsection{Research Question}

The researcher tried to answer to the following question: whether the position of individual evolves under the international law? And to reveal whether the rights and duties of a legal person are the same or vary from person to person within the same legal system or from one legal system to another?

\subsection{Research Objective}

The purpose of this study is to investigate the development of individual status in the international law.

\section{Methodology}

In order to answer the question, the researcher followed the analytical and comparative method of the relevant laws to solve the problem.

\subsection{The Position of International Jurisprudence on the Status of the Individual}

Jurisprudence does not agree on the status of the individual in international law. Some jurisprudence denies the international legal personality of the individual. ${ }^{2}$

The international jurist Ferdros writes that the individual is not considered to be a person of international law. This law defends the interests of individuals, but the individual enjoys rights and duties not directly, but through his state. ${ }^{3}$

The international jurist Tonkin, G. has argued that the individual has no legal capacity in international law and accordingly is not a subject of international law. ${ }^{4}$

While the international jurist Ian brownlie wrote that there is no general rule that hinders the individual from acquiring an international legal personality, and in certain cases the individual appears as a legal person in the international standard but at the same time there is no benefit in considering the individual as a person of international law. ${ }^{5}$

In an attempt to prove the absence of international legal personality from the individual, Dr. Hamid Sultan wrote that if the communication between the legal rule and the unit is indirect, the international legal capacity of the unit is not proven. ${ }^{6}$

Dr. Shafi'i Muhammad Bashir, the human being is considered the subject of international systems and is also its goal, but this is not sufficient to consider the individual as a person of international law. ${ }^{7}$

\footnotetext{
2 -brownlie, I. (1977) International Law, First Book, Moscow. p. 117, Russian interpreter

- Ghanem, M. (1964) Principles of Public International Law. Cairo, p. 275

- Sultan, H. (1965) General International Law, p. 78

- Ibrahim, A. (1995) General International Law. Part I. The Arab Renaissance Department Cairo, p. 852

- Tonkin, M. (1982) International Law, Moscow, p. 82

- Ferdros,A. International Law, Moscow, 1959, p. 130, translated into Russian

- Morchalov, M. (1971) International Legal Relations, p. 79, translated into Russian.

${ }^{3}$ Ferdros, A. (1959) International Law, Moscow, p. 130, translated into Russian

${ }^{4}$ Tonkin, G. (1982) International Law, Moscow, p 82

${ }^{5}$ brownlie, I. (1977) International Law, Moscow, p. 117, in Russian

${ }^{6}$ Sultan, H. (1962) General International Law in Times of Peace, p. 95

${ }^{7}$ Bashir, Sh. (1971) International Public Law in Peace and War is the source of knowledge. Alexandria p. 243
} 
On the other hand, some jurists and international law interpreters have recognized the international legal personality of the individual, but to varying degrees. For example, the international jurist Hans Kalson presented an effective opinion in which the individual is the only person in international law. ${ }^{8}$

While Dr. Mohammed Aziz Shukri takes a moderate position, considering that the individual has moved beyond the stage of the spot or subject matter of international law to a stage closer to the limited international personality. ${ }^{9}$

This approach is close to that of Dr. Mohamed Talaat al-Ghunaimi. After he developed an opinion about the international legal personality of the individual, he denied the international legal personality to the individual. But later he wrote that when the law establishes rights and duties and mandatory protects its execution when prosecution, he or she may have been admitted to the interviewees with at least some legal personality. ${ }^{10}$

This opinion is also shared by Prof. Rashad Arif, when acknowledging the international legal personality of the individual but it is incomplete ${ }^{11}$, also in this direction, Dr. Ghazi Sabbarini expressed the view that the development that took place in the field of international law led to the creation of a legal status of personality ${ }^{12}$, while Dr. Ali Sadiq Abu Al-Hayef considered the individual to be a member of the international community, in the sense that international law is given an international character ${ }^{13}$.

While the international jurisprudence Gir Hard has argued that human rights conventions and implementing texts or protocols are in force as a result of governments' ratification or accession to them, the individual becomes under certain conditions a parish of international law $^{14}$. Internationalization of human rights has made international law the law of the global humanitarian community after long standing the law of the international community, and concludes that these developments have led the individual to enjoy an international legal status $^{15}$.

Thus, the controversy and debate among jurists and commentators on international law on the legal status of the individual under international law continues between the denigration of his international character and the recognition of it.

But what makes a unit acquired the international legal personality; the jurisprudence required for its acquisition of international legal personality provides two conditions:

1) The individual must be directly addressed with the rules of international law, enjoying the rights and duties, i.e., that he has the capacity and the capacity to perform.

2) The individual must be able to make international legal rules in partnership with others.

See these terms ${ }^{16}$

It is important to note here that no matter how many conditions the unit is supposed to provide in order to rise to the level of the international legal individual and to be marketed by jurists and law interpreters, the decisive, essential and necessary condition is that the individual is directly addressed by the rules of international law rather than an intermediary. As long as the rules of international law address this individual, it arranges rights and imposes obligations as we will see later.

After the radical developments in international law in the aftermath of the Second World War and the important role of the United Nations, the rules of international law address the individuals directly and not through States, which entitle them to rights and impose obligations on them. These rights and obligations are derived directly from the rules in the international legal order.

If the individual's inability to create a legal basis is the obstacle to the attainment of international legal personality, individuals of international law are not identical, do not have the same status and the same capacity.

\footnotetext{
${ }^{8}$ Keelson . h.principles of international law new York 1966.p 39

${ }^{9}$ Shukri, M. (1988) An Introduction to International Law, Damascus. p. 191

${ }^{10} \mathrm{Al}$ - Ghunaimi,M. (1982) mediator in the peace law, Alexandria, p. 362.

${ }^{11}$ Al- Saed,R. (2001) General International Law in its new form, Amman, p. 222

${ }^{12}$ Al-Sabarini, Gh. (1992) Al-Wajiz in Principles of Public International Law, Department of Culture, Amman, p. 135

${ }^{13}$ Abu Al-Hayef, A. (1972) General International Law Knowledge Establishment Alexandria, p. 263.

${ }^{14}$ Avant, G. (1970) Law between Nations. Introduction to Public International Law, Part I. Al Efaq New House. Beirut p. 206

${ }^{15}$ Alwan, M. (2003) International Law Human Rights, World of Thought, Vol. 31 No. 4, p. 175

${ }^{16}$ Sultan, H. (1962) General International Law in Time of Peace, p. 95

- International Public Law (1999) 2nd edition. Moscow, pp. 114-120
} 
It is true that an individual cannot contribute to the making of the legal rule at this moment in the development of the structure of international relations, but this condition is not necessary, there are people addressed by international law and enjoy the international legal personality, but do not have the ability to contribute to the legal rules which is the right of States and international organizations only.

The individual becomes more and more effective as the revolution of communication, information, transportation, and international contracts grows, and it is not unlikely that the day will come when he will become a partner in making the international legal base.

The State is not the only person in international law and it is inconceivable that there are other people, as some suggest, and the individual is not the only person in international law and it is inconceivable that there are other people and others have gone.

It is true that the State is the most important person of international law and the most effective party in international relations, but as international jurist Edward Jimensen de Rizaga has argued that nothing in international law gives the State the monopoly of the international legal personality to the State only ${ }^{17}$.

The International Jurisprudential dispute in the Legal Character of International Organizations for some time concluded that the resolution of the international judiciary was clear and unequivocal and declared in 1949 that the United Nations has a legal personality under international law so that this Organization can achieve its objectives $^{18}$.

Here we must acknowledge the fact that the persons of international law as mentioned above are not identical and have the same capacity. The international legal personality can be said to be of two types:

- $\quad$ The principal persons, States and international organizations

- $\quad$ Secondary persons, including the individual

\subsection{The Rules of International Law Address Individuals Directly}

The rules of international law address individuals through a large number of international treaties. Here we will mention some treaties:

\subsubsection{International Treaties Directly Regulating Individual Rights}

The rules of international public law, which address individuals directly and without intermediaries, have increased and have entailed rights and obligations.

The individual became the subject of international law, this concern was reflected in the Charter of the United Nations of $(1945)^{19}$ which established a new principle in international law and international relations (The principle of respect for human rights), the Charter of the United Nations was the cornerstone of the emergence of international human rights law and the emergence of dozens of International instruments dealing with various aspects of human rights and fundamental freedoms, and among the most important international human rights instruments ${ }^{20}$ :

- $\quad$ Universal Declaration of Human Rights, 1948

- International Covenant on Civil and Political Rights, 1966

- International Covenant on Economic, Social and Cultural Rights, 1966

- International Convention Against All Forms of Racial Discrimination, 1965

- International Convention against Torture, 1989

- International Convention on the Child Rights, 1989

And dozens of other international instruments that have established human rights generations:

- The first generation of civil and political rights

- The second generation of economic, social and cultural rights

- Third generation of solidarity rights

\footnotetext{
${ }^{17}$ Rachata, E. (1983) Contemporary International Law. Progress house, Moscow, p. 256, translated into Russian from Spanish

${ }^{18}$ The Advisory Opinion in (1949) of the International Court of Justice in the Kuten Bernadon Case and the Compensation for Damage to United Nations Staff, CJ Recueil, p.179

${ }^{19}$ See Preamble, Article 1, article 13, 55, 56, 62, 68, and 76

${ }^{20}$ See Human Rights Instruments, International Instruments Group, United Nations, New York, 1988
} 
It became a human right to enjoy these rights regardless of the difference in gender, language, religion, wealth, and strong political or non-political opinion, since these rights are universal, interdependent, and indivisible and human rights norms are of a peremptory nature.

The relationship between the individual and the State has become an international affair and has emerged from the very core of the State's internal authority.

And that gross and systematic violation of human rights is threatening international peace and security, which requires the intervention of international bodies.

The unprecedented developments in international legal relations, in their broad sense, have produced international legal systems for the protection of human rights at the global and regional levels, thus enhancing the international standing of the individual.

\subsubsection{International Treaties That Directly Impose Obligations on the Individual}

The obligations established by the rules of international law directly on individuals have increased with the establishment of the principle of international criminal responsibility, from the end of the Second World War to the present. The best evidence of this is the Nuremberg Tribunal, the Tokyo Tribunal, Rwanda Tribunal ${ }^{21}$, Yugoslavia Tribunal $^{22}$ and finally the International Criminal Tribunal ${ }^{23}$.

The individuals who commit the most serious crimes against the international community are prosecuted before the relevant international criminal tribunals regardless of the official status of the individual ${ }^{24}$.

International crimes against which individuals are prosecuted are classified ${ }^{25}$ :

- War Crimes

- Genocide

- Crimes against humanity

- Crimes of aggression

There is a very large number of international treaties address individuals directly and have obligations that must be met under international criminal responsibility, including:

- International Convention for the Suppression and Punishment of the Crime of Genocide of 1948

- The four Geneva Conventions of 1949

- International Convention against War Crimes of 1968

- Rome Statute of the International Criminal Court of 1988 and others

\subsection{The Right to Submit Complaints and Claims at the International Level}

With unprecedented developments in international law, an individual can file complaints and allegations directly with international judicial and other bodies and institutions to lift violations and obtain compensation for damages.

With unprecedented developments in international law, an individual can file complaints and allegations directly with international judicial and other bodies and institutions to lift violations and obtain compensation for damages.

2.3.1 The Right of the Individual to File Complaints with the Competent International Committees

At the international level, an individual can file complaints with the competent committees in the event of a violation of one of his fundamental rights.

The relevant committees are those committees established under international treaties to monitor the implementation and application of human rights treaties

There are currently six committees with powers to receive and consider complaints from individuals:

\footnotetext{
${ }^{21}$ The Rwander Tribunal was established by the Security Council in its resolution 827 (1993) of 25 May 1993

${ }^{22}$ Established by Security Council resolution 995 of 8 November 1949

${ }^{23}$ Established under an international treaty, the Rome Statute of the International Criminal Court of 1998, which entered into force on 1 July 2002

${ }^{24}$ See article 27 of the Statute of the International Criminal Court

${ }^{25}$ See article 5 of the Statute of the International Criminal Court
} 
- The Human Rights Committee established under the International Covenant on Civil and Political Rights, 1966

- Committee on Economic and Social Rights established under the International Covenant on Economic, Social and Cultural Rights, 1966

- Committee on the Elimination of Racial Discrimination established under the International Convention on the Elimination of All Forms of Racial Discrimination, 1965.

- Committee on the Elimination of Discrimination against Women established under the International Convention on the Elimination of Discrimination against Women, 1979

-Committee against Torture established under the International Convention on the Protection of the Rights of All Migrant Workers and Their Families, 1990

- Committee for the Protection of All Migrant Workers and their Families established under the International Convention on the Protection of All Migrant Workers and Their Families, 1990.

There are forms of complaints that must be complied with and the specific requirements, including exhaustion of internal audit methods, are met $^{26}$.

Within the framework of UNESCO, an individual is entitled to lodge complaints with the UNESCO Committee on conventions, recommendations and notification on human rights violations ${ }^{27}$.

As well as within the framework of the international labor organization (ILO) The worker is entitled to lodge a complaint against a Member State that has failed to comply with the ILO Convention to which it is a party to the International Labor Conference to consider this complaint in accordance with the procedures provided for in the International Labor Organization (ILO) ${ }^{28}$.

2.3.2 The right of the individual to litigate cases at the human rights courts and international judicial institutions at the regional level. International human rights protection regimes allow individuals to prosecute the State, as is the case with the European Court of Human Rights, which is under compulsory jurisdiction under Protocol XI of 1998 and the African Court on Human and Peoples' rights ${ }^{29}$.

In accordance with article 90 of the United Nations Convention on the Law of the Sea 1982, an individual has the right to litigate cases against the State party to the Convention at the Seabed Disputes Chamber of the International Tribunal for the Seabed of the $\mathrm{Sea}^{30}$, the European individual in the three European Union countries and the Council of Europe can file suit with the European Court of Justice ${ }^{31}$.

\section{Conclusion}

Thus, monitoring the remarkable developments in international relations, and international law both at the international and regional regimes levels, specially the European regional system. The individual is receiving great attention from the international community. The rules of public international law are directly addressing individuals, entailing and protecting rights, imposing obligations on them and implementing them, establishing international legal mechanisms to achieve this, and the individual becoming increasingly prominent in international legal relations as such. We can say that the individual has an international legal personality but is limited and can be developed with increasing overlap between the legal systems, the international legal order and the domestic legal order.

\section{References}

Abu- Hayef, A. (1972). General International Law Knowledge Establishment Alexandria, p. 263.

Al- Ghunaimi, M. (1982). Mediator in the peace law, Alexandria, p. 362.

Al-Sabarini, Gh. (1992). Al-Wajiz in Principles of Public International Law, Department of Culture, Amman, p. 135.

\footnotetext{
${ }^{26}$ Hüfner, K. (2002) How to file complaints against human rights violations Guide to German individuals and non-governmental organizations Preparation of the United Nations Secretariat and the German Committee of the United Nations Educational, Scientific and Cultural Organization 3rd edition, Bonn

${ }^{27}$ See Executive Board Resolution No. 104. 3 April 1978

${ }^{28}$ See article 24 of the Constitution of the International Labor Organization

${ }^{29}$ The African Court of Human Rights was established under the Additional Protocol to the 1998 African Charter on Human and Peoples' Rights, which came into force in 2003

${ }^{30}$ See Article 190 of the Montgopian Convention on the Law of the Sea, 1982.

${ }^{31}$ Shafi'i, B. (1979) General International Law on Peace and War, op. Cit., pp. 243-244
} 
Al- Saed, R. (2001). General International Law in its new form, Amman, p. 222.

Alwan, M. (2003). International Law Human Rights. World of Thought, 31(4), 175.

Avant, G. (1970). Law between Nations, Introduction to Public International Law, Part I. Al Efaq New House. Beirut p. 206.

Bashir, Sh. (1971). International Public Law in Peace and War is the source of knowledge. Alexandria p. 243

Brownlie, I. (1977). International Law, First Book, Moscow. p. 117, Russian interpreter.

Ferdros, A. (1959). International Law, Moscow, p. 130, translated into Russian.

Ghalioun et al. (2005). An Analytical Perspective on Human Rights through the Charters and Organizations' Declarations, 13-14 in: Human Rights: Global, Islamic and Arab Perspectives.

Ghanem, M. (1964). Principles of Public International Law. Cairo, p. 275.

Hüfner, K. (2002). How to file complaints against human rights violations Guide to German individuals and non-governmental organizations Preparation of the United Nations Secretariat and the German Committee of the United Nations Educational, Scientific and Cultural Organization 3rd edition, Bonn.

Ibrahim, A. (1995). General International Law. Part I. The Arab Renaissance Department Cairo, p. 852.

International Public Law. (1999). 2nd edition, Moscow, pp. 114-120.

Keelson, H. (1966). Principles of international law New York, p. 39.

Morchalov, M. (1971). International Legal Relations, p. 79, translated into Russian.

Rachata, E. (1983). Contemporary International Law. Progress house, Moscow, p. 256, translated into Russian from Spanish.

Shafi'i, B. (1979). General International Law on Peace and War, op. Cit., pp. 243-244.

Shukri, M. (1988). An Introduction to International Law, Damascus. p. 191.

Sultan, H. (1962). General International Law in Times of Peace, p. 95.

Sultan, H. (1965). General International Law, p. 78.

The Advisory Opinion in (1949) of the International Court of Justice in the Kuten Bernadon Case and the Compensation for Damage to United Nations Staff, CJ Recueil, p.179.

Tonkin, M. (1982). International Law. Moscow, p. 82.

\section{Copyrights}

Copyright for this article is retained by the author(s), with first publication rights granted to the journal.

This is an open-access article distributed under the terms and conditions of the Creative Commons Attribution license (http://creativecommons.org/licenses/by/4.0/). 